INKLUSIF : Jurnal Pengkajian Penelitian Ekonomi dan Hukum Islam (Vol:5, No:1 Juni 2020)

Published by Pascasarjana IAIN Syekh Nurjati Cirebon, Indonesia. p-ISSN: 2303-2669, e-ISSN: 2548-9631
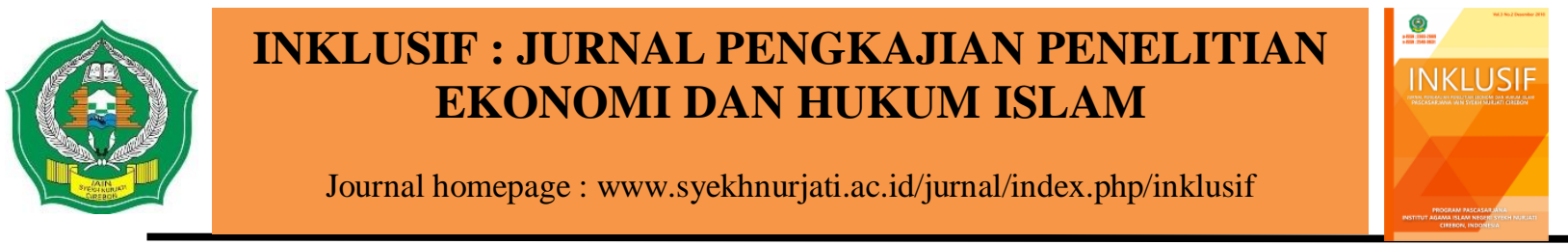

\title{
ZAKAT PRODUKTIF DALAM PEMBERDAYAAN USAHA MIKRO KECIL MENENGAH (UMKM) DAN DAMPAKNYA TERHADAP PENINGKATAN KESEJAHTERAAN MUSTAHIK : MODEL CIBEST DI BAZNAS KABUPATEN CIREBON
}

\author{
Nurjanah \\ Jurusan Ekonomi Syari'ah Pascasarjana IAIN Syekh Nurjati Cirebon \\ Email: nurjanahnorfairuz00@gmail.com
}

\section{Artikel info:}

ABSTRACT

Received: 1

September

2019

Accepted: 4

September

2019

Available

online: 24 Juni

2020
This study intends to examine changes in household income Mustahik before and after receiving productive zakat funds based on the CIBEST Model. The results showed that based on the CIBEST model the material poverty index decreased by 0.24 or 24 percent out of material poor conditions after the provision of productive zakat and guidance. Furthermore the spiritual poor index from 0.12 or 12 percent fell to 0 percent after the existence of productive zakat funds and guidance. Likewise, absolute poverty from 0.1 or 1 percent to 0 percent of households must come out of absolute poverty. And the welfare index has increased by 46 percent of zakat after zakat assistance and guidance and managed to enter into the welfare category.

Keywords: Productive Zakat; Empowerment; CIBEST; UMKM

\section{ABSTRAK}

Penelitian ini bermaksud mengkaji perubahan pendapatan rumah tangga Mustahik sebelum dan setelah mendapatkan bantuan dana zakat produktif berdasarkan Model CIBEST. Hasil penelitian menunjukkan berdasarkan model CIBEST Indek kemiskinan material menurun sejumlah 0,24 atau 24 persen keluar dari kondisi miskin material setelah adanya bantuan zakat produktif dan bimbingan. Selanjutnya indeks miskin spiritual dari 0,12 atau 12 persen turun menjadi 0 persen setelah adanya bantuan dana zakat produktif dan bimbingan. Begitu juga miskin absolut dari 0,1 atau 1 persen menjadi 0 persen rumah tangga mustahik keluar dari kondisi miskin absolut. Dan indeks kesejahteraan ada kenaikan sejumlah 46 persen zakat setelah adanya bantuan zakat dan bimbingan dan berhasil masuk ke dalam kategori sejahtera.

Kata Kunci: Zakat Produktif; Pemberdayaan; CIBEST; UMKM 


\section{PENDAHULUAN}

Masalah ekonomi makro yang dihadapi oleh Indonesia adalah kemiskinan. Menurut Badan Pusat Statistik (BPS) kemiskinan Indonesia pada tahun 2017 mencapai 26,58 juta orang atau (10,12 persen) dan Maret 2018 turun menjadi 25,95 juta orang (9,82 persen). ${ }^{1}$ Termasuk kota Cirebon kemiskinan sudah mencapai 288,49 ribu jiwa. ${ }^{2}$ Menurut ketua Umum Baznas Propinsi Jawa Barat, KH Suryani Ihsan, Bahwa pengemis dan gelandangan di Jawa Barat menjelang Ramadhan meningkat jumlahnya hingga 60-70\%. Sementara data dari Dinas Sosial Kabupaten Cirebon menunjukkan bahwa jumlah Rumah Tangga Miskin (RTM) mencapai 96.971 keluarga, jumlah rumah tidak layak huni (Rutilahu) mencapai 16.923 unit, jumlah pengemis 505 orang, dan jumlah gelandangan 219 orang. $^{3}$

Berdasarkan data kemiskinan tersebut perlu adanya instrumen dalam mengurangi kemiskinan dan meningkatkan kesejahteraan masyarakat Indonesia. Dan salah-satu instrumen untuk meningkatkan kesejahteraan dan mengurangi kemiskinan adalah zakat. Zakat sebagai sumber keuangan publik yang besar tidaklah mungkin dapat mencapai tujuannya mewujudkan kesejahteraan masyarakat apabila tidak dikelola oleh lembaga yang amanah, profesional, dan transparan. Oleh karena itu QS. At-Taubah :60 terkait dengan penyaluran zakat Allah menjelaskan adanya lembaga pengelola (Amil) yang bertugas merencanakan, melaksanakan, dan mengawasi, penerimaan dan pendayagunaan zakat sesuai dengan ketentuan syariat. Dengan pengelola yang amanah, maka zakat sebagai sumber keuangan publik yang dikumpulkan dari masyarakat kelas menengah ke atas dan disalurkan kepada masyarakat kelas bawah benar-benar dirasakan oleh masyarakat secara merata sehingga tercipta kehidupan masyarakat yang aman, tentram, dan sejahteran (baldatun thoyibatun wa robbun ghofur). ${ }^{4}$

Badan Amil Zakat yang dikelola pemerintah sudah memberikan wadah sebagai instrumen dalam pengentasan kemiskinan. Karena kemiskinan merupakan masalah ekonomi dan zakat yang punya dimensi sosial diantaranya dimensi ekonomi, dimensi sosial dan dimensi spiritual. Dalam dimensi sosial dapat mewujudkan harmonisasi kondisi sosial masyarakat, sedangkan dalam dimensi ekonomi dapat mewujudkan pertumbuhan ekonomi yang bertujuan untuk meningkatkan kesejahteraan masyarakat dan mengurangi kemiskinan. Untuk dimensi spiritual, sebagai perwujudan keimanan seseorang kepada Allah. ${ }^{5}$

\footnotetext{
${ }^{1}$ Badan Pusat Statistik, "Satistik Kependudukan Jakarta," 2018, https://www.bps.go.id.

2 Badan Pusat Statistik, Satistik Kependudukan Cirebon, 2016.

3 Badan Amil Zakat Nasional, Memori Pelaksanaan Tugas Badan Amil Zakat Nasional Kabupaten Cirebon Periode 2011-2016 (Kabupaten Cirebon, 2016).12.

${ }^{4}$ Badan Amil Zakat Nasional.3.

${ }^{5}$ Irfan Syauqi Beik and Laily Dwi Arsyianti, 'Construction Of Cibest Model As Measurement Of Poverty And Welfare Indices From Islamic Perspective', Al-lqtishad: Journal of Islamic Economics, 2015 Vol VIII No 1.89.
} 
Menurut Nurkse dalam Cesar Masyarakat miskin umumnya sudah terjebak dalam lingkaran setan kemiskinan atau Vicious Circle of Poverty. menyebutkan bahwa lingkaran setan sebagai suatu deretan melingkar dimana satu sama lain memiliki kekuatan yang sama untuk bereaksi sedemikian rupa hingga menempatkan seseorang dalam keadaan melarat yang berkepanjangan. Teori lingkaran setan ini berawal dari rendahnya produktivitas masyarakat sebagai dampak dari kurangnya modal usaha. Dimulai dari tingkat produktivitas yang rendah mengakibatkan rendahnya tingkat pendapatan. Rendahnya tingkat pendapatan mengakibatkan rendahnya tingkat tabungan dan permintaan. Selanjutnya tingkat tabungan yang rendah berakibat pada rendahnya tingkat investasi dan kurang nya modal. Kekurangan modal ini kembali kepada fase rendahnya produktivitas yang dihasilkan. Lingkaran ini akan terus berlangsung apabila tidak terdapat perubahan yang membuat terputusnya lingkaran setan kemiskinan ini. Upaya utama yang dapat dilakukan untuk memutus lingkaran setan kemiskinan ini adalah memberikan tambahan modal kepada masyarakat miskin yang disertai dengan bimbingan dan pendampingan guna meningkatkan produktivitas. ${ }^{6}$

Diantaranya Baznas Kabupaten Cirebon yang sudah mempunyai progam selain zakat konsumtif (Jangka pendek) tetapi zakat produktif (Jangka Panjang) untuk pemberdayaan ekonomi mustahik melalui UMKM. Di sini peneliti lebih fokus ke mustahik sekaligus pelaku UMKM yang tidak mempunyai akses pembiayaan di perbankan sekaligus mempunyai penghasilan kecil dari asnaf yang lain. Berbagai kendala yang dihadapi oleh pelaku UMKM diantaranya modal. Oleh karena itu zakat produktif menjadi instrumen alternatif yang menguntungkan untuk mengembangkan UMKM sekaligus sebagai pemutus lingkaran setan tersebut. UMKM mempunyai peranan besar dalam pertumbuhan ekonomi dan mengurangi kemiskinan di Indonesia. Terbukti pasca krisis 1997 dan 1998 hanya UMKM yang mampu bertahan. UMKM juga menjadi sumbangsih terbesar penyerapan tenaga kerja di Indonesia. Untuk itu dalam penggunaan zakat sebagai isntrumen mengurangi kemiskinan dan meningkatkan kesejahteraan dibutuhkan suatu model yang dapat mengukur aspek-aspek lainnya seperti aspek spitirual. Salah satu model yang dapat digunakan yaitu Center for Islamic Bisnis and economic Studies (CIBEST) model. ${ }^{7}$ Adapun perumusan masalah dalam penelitian ini adalah bagaimana hubungan zakat produktif bagi pengembangan UMKM, Bagaimana perubahan Pendapatan rumah tangga mustahik Pelaku UMKM sebelum dan sesudah mendapatkan zakat produktif, Bagaimana klasifikasi kuadran rumah tangga mustahik dan indeks berdasarkan Model CIBEST

\section{METODE PENELITIAN}

\footnotetext{
${ }^{6}$ Caesar Pratama, "Pendayagunaan Zakat Produktif Dalam Mengurangi Kemiskinan Berdasarkan CIBEST Model (Studi Kasus: PT Masyarakat Mandiri Dompet Dhuafa)," 2015, 5.

${ }^{7}$ Beik and Arsyianti, "Construction of CIBEST Model as Measurement of Poverty and Welfare Indicesfrom Islamic Perspective.Al-Iqtishad.," 93-94.
} 
Penelitian ini menggunakan jenis penelitian lapangan (field reseach) yang menggunakan desain penelitian campuran (Mixed Methodologi). Populasi dalam penelitian ini adalah Mustahik yang sekaligus rumah tangga yang berperan sebagai pelaku Usaha Mikro Kecil Menengah (UMKM) yang bergabung di BMT Tuan Jaler di bawah naungan Baznas Kabupaten Cirebon. Adapun semua jumlah Mustahik yang tergabung di BMT Tuan Jaler dan mengikuti program masyarakat Mandiri adalah kurang lebih yang aktif 50 orang mustahik dan tersebar di seluruh Kabupaten Cirebon. Penarikan sampel dilakukan secara acak atau disebut teknik random sampling yaitu mengambil sampel secara acak dari sampling frame yang sudah ditentukan. ${ }^{8}$ Metode analisis data yang digunakan dala penelitian ini adalah menggunakan metode indeks kemiskinan islami Center of islamic Business and Economics Studies (CIBEST).

\section{PEMBAHASAN}

\section{A. Zakat Produktif Bagi Pengembangan UMKM}

Keberadaan UMKM yang paling terlihat adalah kemampuannya di dalam penyerapan tenaga kerja yang berdampak pada berkurangnya pengangguran. Menurut Partono dan Soejoeno dalam wulansari dan Setiawan, dalam pembangunan ekonomi di Indonesia UMKM selalu digambarkan sebagai sektor yang mempunyai peranan sangat penting, hal ini dikarenakan UMKM dapat menyerap tenaga kerja yang berpendidikan rendah dan hidup dalam kegiatan usaha kecil baik tradisional maupun modern. Ada beberapa keunggulan UMKM terhadap usaha besar antara lain sebagai berikut yaitu pertama, Inovasi dalam teknologi yang telah dengan mudah terjadi pengembangan produk. Kedua, Hubungan kemanusiaan yang akrab dalam usaha kecil. Ketiga, Kemampuan menciptakan kesempatan kerja cukup banyak. Keempat, Fleksibilitas dan kemampuan menyesuaikan diri terhadap kondisi pasar yang berubah dengan cepat dibandingkan dengan perusahaan skala besar yang pada umumnya birokratis. Kelima, Terdapatnya dinamisme manajerial dan peranan kewirausahaan. ${ }^{9}$ Terbukti total pekerja di Indonesia menurut BPS tahun 2016 mencapai 110 juta orang, sekitar 107 juta orang masuk dalam struktur UMKM. Hal ini menunjukkan porsi orang yang bekerja sebagai UMKM mencapai sekitar 97,3\%. Berdasarkan data Badan Pusat Statistik (BPS), jumlah UMKM di Indonesia mencapai 56,5 juta orang. Jika dirata-rata maka satu unit UMKM memiliki dua pekerja. Dilihat dari jumlah unit usahanya, porsi UMKM mencapai lebih dari 99,9\% dari total unit usaha di Indonesia. Namun, produktifitas UMKM tidak linier dengan jumlah usaha dan pekerjanya. Dilihat dari sumbangan terhadap Produk Domestik Bruto (PDB), porsi UMKM hanya sekitar 59\%, artinya dengan porsi unit usaha sebesar 99,9\%, porsi tenaga kerja sebesar 97,3\%, UMKM hanya bisa menyumbang 59\% PDB. Hal ini berarti produktifitas UMKM di Indonesia masih sangat rendah. UMKM saat ini masih

\footnotetext{
${ }^{8}$ B Juanda, Metodologi Penelitian Ekonomi Dan Bisniso Title (Bogor, 2009).1-2.

${ }^{9}$ Sintha Dewi Wulansari, "ANALISIS PERANAN DANA ZAKAT PRODUKTIF TERHADAP PERKEMBANGAN USAHA MIKRO MUSTAHIK (PENERIMA ZAKAT) (Studi Kasus Rumah Zakat Kota Semarang)E,” 2013.1-15.
} 
menghadapi kendala salah satunya yaitu modal. ${ }^{10}$ Banyak usaha-usaha pemeirntah yang telah dilakukan tetapi banyak masyarakat yang belum merasakan bantuan tersebut. Untuk itu, instrumen yang penting agar masyarakat miskin dapat mengakses modal yaitu dengan zakat produktif. Zakat produktif ini dikembangkan dalam bentuk modal usaha.

Dana zakat yang disalurkan ke arah produktif harus ditandatangani oleh Lembaga yang mampu melakukan pembinaan, pendampingan, dan monitoring kepada para Mustahik yang sedang melakukan kegiatan usaha agar dapat berjalan dengan baik. ${ }^{11}$ Konsep ini dikembangkan karena mikro mustahik tidak mampu mengakses modal ke lembaga keuangan formal seperti bank dan lain-lain. Melalui program bergulir bagi para pengusaha mikro yang tergolong mustahik. setelah mendapatkan bantuan modal bergulir, masyarakat bisa digunakan bisa diberikan pembinaan secara rutin dengan tujuan agar usaha yang dibangun dapat berkembang sampai merubah perekonomian mustahik. Yakni perubahan status dari mustahik menjadi muzaki.

Untuk memaksimalkan tujuan dari zakat produktif itu, perlu adanya regulasi dan prosedur yang dibuat, Prosedur ini dimulai dari persiapan usaha, pengawasan usaha, dan pendampingan usaha. ${ }^{12}$ Upaya-upaya untuk mengembangkan potensi mustahik ini perlu adanya pemberdayaan untuk mencapai masyarakat mandiri. Pemberdayaan menurut Edi Suharto dalam bukunya yang berjudul Membangun Masyarakat Memberdayakan Rakyat,Pemberdayaan adalah serangkaian kegiatan untuk memperkuat kekuasaan atau keberdayaan kelompok yang lemah dalam masyarakat, dengan cara mendorong, memotivasi, dan membangkitkan kesadaran akan potensi yang dimiliki dan berupaya untuk mengembangkan potensi itu menjadi sebuah tindakan yang nyata. ${ }^{13}$

Darwan Triwibowo dan Nur Iman Subono juga dalam bukunya yang berjudul, Meretas Arah Kebijakan Sosial Baru Di Indonesia menjelaskan bahwa Pemberdayaan merupakan alat untuk menujukkan pada keadaan atau hasil yang ingin dicapai oleh perubahan sosial, yaitu masyarakat yang berdaya, memiliki kekuasaan atau mempunyai pengetahuan dan kemampuan dalam memenuhi kebutuhan hidupnya baik bersifat fisik, ekonomi, maupun sosial. ${ }^{14}$ Sedangkan tujuan dari pemberdayaan usaha kecil, mikro dan menengah menurut undang-undang No 20 tahun 2008 tentang UMKM adalah ${ }^{15}$

\footnotetext{
${ }^{10}$ www.depok.pos, “Peran Zakat Terhadap Perkembangan UMKM Di Indonesia," 2018.

${ }^{11}$ I.R Fitriani, "Pola Distribusi Zakat Dalam Upaya Meningkatkan Kesejahteraan Jama'ahMajelis Taklim Al-Hidayah Rejosari Gunungpati (Studi Kasus Baznas Provinsi Jawa Tengah)" (UIN Walisongo, 2015).7.

12 Mursyid, Mekanisme Pengumpuan Zakat, Infak Dan Shadaqaha (Menurut Hukum Syara' Dan UU) (Yogyakarta: Magistra Insania Press, 2006),5.

13 Edi Suharto, Membangun Memberdayakan Rakyat, Kajian Strategi Pembangunan Kesejahteraan Sosial \& Pekerjaan Sosial (Bandung: PT Refika Aditama, 2005).56.

${ }^{14}$ Darwan Triwibowo, Meretas Arah Kebijakan Sosial Baru Di Indonesia, Jakarta:Pustaka LP3ES. (Jakarta: Pustaka LP3ES, 2005).95.

15 Putra zairisnaldi, "Pemberdayaan UMKM Menurut UU No 28 Tahun 2008 Tentang UMKM," https://www.academia.edu.15010904, 2019.
} 
1. Menwujudkan struktur perekonomian nasional yang seimbang, berkembang dan berkeadilan.

2. Menumbuhkan dan mengembangkan kemampuan usaha mikro, kecil dan menengah menjadi usaha yang tangguh dan mandiri.

3. Meningkatkan peran usaha UMKM dalam pembangunan daerah, penciptaan lapangan kerja, pemerataan pendapatan, pertumbuhan ekonomi dan pengentasan kemiskinan.

Tujuan pemberdayaan ini oleh Baznas untuk dapat mencapai kesejahteraan. Kesejahteraan yang dimaksud adalah kesejahteraan syariah. Ada dua jenis ekonomi kesejahteraan, yaitu ekonomi kesejahteraan ekonomi konvensional dan kesejahteraan syariah. Kesejahteraan konvensional hanya menekankan pada kesejahteraan material saja, dengan mengabaikan kesejahteraan spiritual dan moral. Sedangkan kesejahteraan syariah bertujuan mencapai kesejahteraan menyeluruh, yaitu kesejahteraan material, spitual dan moral. Manisfestasinya tidak hanya nilai ekonomi, tetapi juga nilai moral dan spiritual, nilai sosial dan nilai politik islami. Atau dengan kata lain kesejahteraan syariah mempunyai konsep yang lebih komprehensif. ${ }^{16}$

Agar dana zakat setidaknya ada dua model distribusi yaitu konsumtif dan produktif. Kedua model di atas masing-masing di bagi menjadi dua yaitu konsumtif tradisional dan konsumtif kresatif, dan produktif konvensional serta produktif kreatif. Konsumtif tradisional yaitu Penyaluran secara konsumtif tradisional adalah zakat dibagikan kepada mustahik langsung untuk dikonsumsi sehari-hari, Konsumtif kreatif adalah dana zakat dirupakan barang konsumtif dan digunakan untuk membantu orang miskin dalam mengatasi permasalahan sosial ekonomi yang dihadapinya, Produktif konvensional adalah Pendistribusian zakat secara produktif konvensional adalah dana zakat diberikan dalam bentuk barang-barang produktif. Produktif kreatif adalah Pemberian zakat secara produktif kreatif adalah zakat diberikan dalam bentuk pemberian modal bergulir ${ }^{17}$

\section{B. Pendapatan Rumah Tangga Mustahik Sebelum Dan Sesudah Mendapatkan Zakat Produktif}

Berdasarkan hasil pengelolaan data dengan menggunakan uji t stastistik berpasangan dengan menggunakan SPSS, maka didapatkan hasil signifikansi sebesar 0.000. nilai signifikansi ini lebih kecil dari taraf nyata 5 persen sehingga hipotesanya menolak Ho. Yaitu, pendapatan rumah tangga mustahik masyarakat mandiri Baznas Kabupaten Cirebon setelah mendapatkan bantuan dana zakat produktif berbeda nyata pada taraf $\alpha=5$ persen terhadap pendapatan rumah tangga mustahik sebelum mendapatkan bantuan dana zakat produktif. Uji $t$ ini menggambarkan rata-rata pendapatan sebelum dan sesudah mendapatkan bantuan dana zakat produktif. Rata- rata pendapatan rumah tangga ini sebelum mendapatkan dana zakat

\footnotetext{
${ }^{16}$ M.A. Mannan, MaShort Introduction in Islamic Philosophy, Theology and Mysticism (England,Oxford,: Oneworld Publications, 1970).358.

17 Departemen Agama, Manajemen Pengelolaan Zakat, Direktorat Pengembangan Zakatdan Wakaf (Jakarta, 2005).33.
} 
produktif pada kisaran $\mathrm{Rp} 1.450 .000$ di mana rata-rata ini menunjukkan di atas garis kemiskinan material akan tetapi setelah mendapatkan bantuan zakat produktif rata-rata pendapatan mustahik berada pada Rp 1.894 .000 dia mana rata-rata ini meningkat masih di atas garis kemiskinan material. Sehingga peneliti dapat menyimpulkan bahwa adanya bantuan zakat produktif memberikan pengaruh yang sangat signifikan pada perubahan pendapatan mustahik. Hasil uji t juga ini tidak bertentangan dengan hipotesis penelitian yang menyatakan ada perbedaan rata-rata sebelum dan sesudah adanya bantuan dana zakat produktif di BMT Tuan Jaler di bawah naungan Baznas Kapubaten Cirebon

\section{Model CIBEST}

Model CIBEST adalah Salah satu model yang dapat digunakan yaitu Center for Islamic Bisnis and economic Studies (CIBEST) model. Yaitu, metode pengukuran kemiskinan berdasarkan perspektif islam dengan cara menyeimbangkan aspek material dan aspek spiritual. ${ }^{18}$ Atau dengan kata lain model CIBEST ini adalah sebuah aplikasi untuk mengukur tingkat kesejahteraan dalam perspektif islam. ${ }^{19}$ Model ini dikembangkan oleh Irfan Syauqi Beik dan Laily Dwi Arsyianti pada tahun 2014 dan telah dipresentasikan pada seminar Workshop on Development a framework for Maqosid AL-Shariah Based Indeks of Socio Economic Development yang diselenggarakan oleh Islamic Research and Training Institute of islamic mah Bank (IRTI-IDB). Perhitungan yang digunakan dalam penelitian ini adalah nilai Material Value (MV) atau garis kemiskinan rumah dan pendapatan rumah tangga per bulan. Material Value ini adalah sebuah alat untuk mengukur standar minimal material yang harus dipenuhi oleh rumah tangga. Nilai MV diperoleh dengan mengalikan harga barang dan jasa yang dikonsumsi $(\mathrm{Pi})$ dengan jumlah barang barang minimal barang dan jasa yang dibutuhkan (Mi). secara matematis, MV dapat dirumuskan sebagai berikut:

$$
\mathrm{MV}=\sum_{i=1}^{n} \mathrm{PiMi}
$$

Keterangan :

$\mathrm{MV}=$ Standar minimal material yang harus dipenuhi oleh rumah tangga ( $\mathrm{Rp}$ atau mata uang lain) atau bisa disebut garis kemiskinan Material

$\mathrm{Pi}=$ Harga barang dan Jasa (Rp atau mata uang lain)

$\mathrm{Mi}=$ Jumlah minimal barang dan jasa yang dibutuhkan.

Namun, karena adanya keterbatasan dalam penelitian ini, maka nilai MV yang digunakan dalam penelitian ini adalah nilai MV yang sudah ada yaitu garis kemiskinan material Kabupaten Cirebon yang akan dijadikan sebagai garis kemiskinan rumah tangga per kapita perbulan. Menurut tsani perhitungan garis kemiskinan diperoleh dengan mengalikan garis kemiskinan perkapita perbulan dengan rata-rata besaran ukuran rumah tangga. Rata-rata

\footnotetext{
${ }^{18}$ T. Beik, I. S., \&lrawan, "Zakat TerhadapKemiskinan Dan Kesejahteraan Mustahik (Kasus: BAZNAS Provinsi Jawa Tengah). AL-MUZARA'AH," 5(1) (2018): 37-50.

${ }^{19}$ Beik and Arsyianti, "CONSTRUCTION OF CIBEST MODEL AS MEASUREMENT OF POVERTY AND WELFARE INDICES FROM ISLAMIC PERSPECTIVE." (2015).93-95.
} 
besara ukuran rumah tangga didapat dari rasio total penduduk dengan jumlah rumah tangga di wilayah yang diteliti. ${ }^{20}$

Garis kemiskinan berdasarkan garis kemiskinan Cirebon tahun 2016 yaitu sebesar Rp.333,758 (BPS Cirebon tahun 2016). ${ }^{21}$ Daerah menjadi tempat dilaksanakannya penelitian meliputi semua kecamatan di kabupaten Cirebon dengan total jumlah penduduk dan rumah tangga di masing-masing wilayah berjumlah 2.126.178 orang dan rumah tangga 580.862 (BPS Cirebon)

Rata-rata ukuran rumah tangga $: 2.126 .178=3,660$

580.862

Sehingga garis kemiskinan rumah tangga (MV) yang diperoleh adalah:

$M V=\operatorname{Rp~333,758~\times 3,660~}$

$=$ Rp 1.221.554 per rumah tangga perbulan

Garis kemiskinan spiritual atau Spiritual Value (SV) diperoleh berdasarkan indikator kebutuhan spiritual dan pemenuhan lima variabel yang menentukkan skor spiritual. Lima indikator variabel tersebut adalah ibadah shalat, zakat, puasa, lingkungan rumah tangga, dan kebijakan pemerintah. Untuk melihat dan menilai skor dari variabel-variabel tersebut digunakan skala likert 1-5 seperti dimana skor 1 mencerminkan kondisi spiritual terburuk, dan skor 5 mencerminkan kondisi spiritual terbaik. contohnya, skor variabel shalat. Skor 5 adalah ketika setiap anggota keluarga melaksanakan shalat wajib rutin berjamaah dan disertai dengan shalatshalat sunnah. Skor 4 adalah melaksanakan shalat wajib rutin tapi tidak selalu berjamaah. Skor 3 adalah melaksanakan shalat wajib tapi tidak rutin. Skor 2 menolak dan tidak percaya dengan konsep shalat, dan skor 1 adalah melarang orang lain shalat. Disebut miskin spiritual ketika skor shalatnya adalah 3 atau lebih rendah dari 3. Dengan konsep ini, maka nilai SV adalah sama dengan 3. Setelah diketahui nilai MV dan SV, maka kemudian keluarga yang diobservasi dimasukkan ke dalam kuadran CIBEST. Kuadran 1 atau kuadran sejahtera adalah ketika pendapatannya di atas nilai MV dan nilai SS-nya di atas nilai SV. Kuadran 2 (kemiskinan material) adalah ketika pendapatan lebih kecil atau sama dengan MV dan nilai SS di atas SV. Kuadran 3 (kemiskinan spiritual) adalah ketika pendapatan di atas nilai MV dan nilai SS lebih kecil atau sama dengan nilai SV. Terakhir, kuadran 4 (kemiskinan absolut) adalah ketika pendapatan dan nilai SS lebih kecil atau sama dengan nilai MV dan SV. Setelah itu baru dihitung nilai indeks masing-masing kuadran. ${ }^{22}$

Penentuan skor spiritual untuk masing-masing individu dalam rumah tangga didasarkan atas formula sebagai berikut:

$$
\mathrm{Hi}=\frac{\mathrm{Vp}+\mathrm{Vf}+\mathrm{Vz}+\mathrm{Vh}+\mathrm{Vg}}{5}
$$

\footnotetext{
${ }^{20}$ Isro Mubarokah, Irfan Syauqi Beik, and Tony Irawan, "Impact of Zakat on Proverty and Welfare of Mustahik (Case: BAZNAS Central Java Province)," Jurnal Al-Muzara'ah 5, no. 1 (2017): 37-50.

${ }^{21} \mathrm{Https}$ //jabar.bps.go.id, “Garis Kemiskinan Cirebon," 2016.

22 Beik, I. S., \&Irawan, "Zakat TerhadapKemiskinan Dan Kesejahteraan Mustahik (Kasus: BAZNAS Provinsi Jawa Tengah). AL-MUZARA'AH," 42-43.
} 


\section{Keterangan :}

$\mathrm{Hi}=$ Skor aktual anggota rumah tangga $\mathrm{ke}-\mathrm{i}$

$\mathrm{Vp}=$ Skor shalat

$\mathrm{Vf}=$ Skor puasa

$\mathrm{Vz}=$ Skor zakat dan infak

$\mathrm{Vh}=$ Skor Lingkungan Kerja

Vg = Skor Kebijakan pemerintah

Setelah melakukan perhitungan SV dan MV maka rumah tangga dapat dikategorikan ke dalam kuadran CIBEST sebagai berikut:

Tabel 1. Kuadran CIBEST

\begin{tabular}{ccc} 
Skor Aktual & SNilai MV & >Nilai MV \\
\hline >Nilai SV & Kaya Spiritual & Kaya Spiritual \\
& Miskin Material & Kaya Material \\
& (Kuadran II) & (Kuadran I) \\
\hline SNilai SV & Miskin Spiritual, & Miskin Spiritual \\
& Miskin material & kaya Material \\
& (Kuadran IV) & (Kuadran III) \\
\hline
\end{tabular}

Sumber: Beik dan Aryanti 2015

Dari tabel dia atas dapat dijelaskan jika nilai skor spiritual rumah tangga (SH) lebih besar dari nilai SV dan pendapatan lebih besar dari nilai SV dan pendapatan lebih besar dari nilai MV maka rumah tangga tersebut masuk ke dalam kategori kuadran I yang tercukupi kebutuhan material dan spiritualnya. Rumah tangga yang memiliki nilai SH lebih besar dari nilai SV dan pendapatan lebih rendah dari nilai MV, maka rumah tangga tersebut masuk ke dalam kategori kuadran II. Rumah tangga dengan skor spiritual lebih kecil dari nilai SV dan pendapatan lebih besar dari nilai MV maka rumah tangga tersebut masuk ke dalam kuadran III. Rumah tangga yang memiliki skor spiritual lebih kecil dari nilai SV dan pendapatan lebih kecil dari MV, maka rumah tangga tersebut masuk ke dalam kategori kuadran IV.

Dari kuadran dapat diketahui indeks CIBESTnya yang terdiri dari indeks kesejahteraan, indeks kemiskinan material, indeks kemiskinan spiritual, indeks kemiskinan absolut. Indeks kesejahteraan yang berupaya untuk menggambarkan kondisi sebaran rumah tangga termasuk dalam kategori sejahtera Formulanya adalah sebagai berikut: ${ }^{23}$

$$
\mathrm{W}=\frac{\mathrm{w}}{\mathrm{N}}
$$

Menurut Beik dan aryanti imdeks kemiskinan material $(\mathrm{pm})$ menggambarkan kondisi rumah tangga yang berada pada kuadran II yang termasuk dalam kategori miskin material.

\footnotetext{
${ }^{23}$ Beik and Arsyianti, "Construction of CIBEST Model as Measurement of Poverty and Welfare Indicesfrom Islamic Perspective.Al-lqtishad". 96.
} 
Rumus untuk menghitung indeks kemiskinan material menurut Beik dan arsyanti adalah sebagai berikut: ${ }^{24}$

$$
\mathrm{Pm}=\frac{\mathrm{Mp}}{\mathrm{N}}
$$

Indeks kemiskinan spiritual (Ps) bertujuan untuk melihat kondisi sebaran rumah tangga yang termasuk dalam kategori rumah tangga yang mengalami kemiskinan spiritual ttapi mampu memenuhi kebutuhan secara meterial secara berkecukupan yang menempati posisi kuadaran III: ${ }^{25}$

$$
P s=\underline{S p}
$$

$\mathrm{N}$

Indeks kemiskinan absolut $(\mathrm{Pa})$ adalah indeks kemiskinan yang berguna untuk melihat penyebaran jumlah rumah tangga yang masuk ke dalam kategori miskin baik material maupun spiritual yang berada pada kuadran IV. ${ }^{26}$

$$
\mathrm{Pa}=\underline{\mathrm{Ap}}
$$

$\mathrm{N}$

Keterangan:

$\mathrm{W}=$ Indeks kesejahteraan $; 0 \leq \mathrm{w} \leq 1$

$\mathrm{w}$ = Jumalah keluarga sejahtera (kaya secara material dan spiritual)

$\mathrm{Pm}=$ Indeks kemiskinanmaterial $0 \leq \mathrm{pm} \leq 1$

$\mathrm{Mp}=$ Jumlah keluarga yang miskin secara material namun kaya secara spiritual

Ps = Indeks kemiskinan spiritual; $0 \leq P s \leq 1$

$\mathrm{Sp}=$ Jumlah keluarga yang miskin secara spiritual namun berkecukupan secara Material

$\mathrm{Pa}=$ Indeks kemiskinan Absolut; $0 \leq \mathrm{Pa} \leq 1$

$A p$ = Jumlah keluarga yang miskin secara spiritual namun berkecukupan secara Material

Untuk menentukkan Kuadran CIBEST peneliti berdasarkan kuesioner dan wawancara kepada mustahik maka tingkat kemiskinan rumah tangga dapat dibagi ke dalam kuadran CIBEST dengan besaran pembagian kategori sebagai berikut:

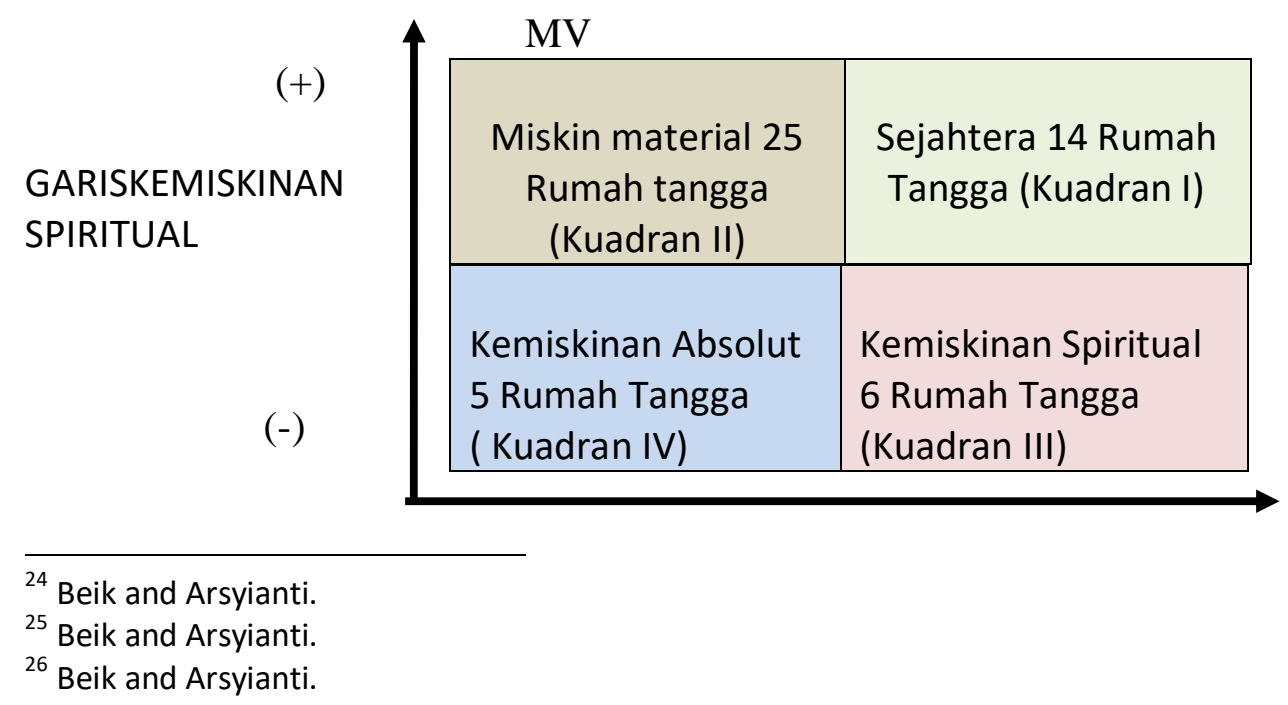




\section{$(-) \quad \operatorname{Rp} \quad(+)$}

GARIS KEMISKINAN MATERIAL

Sumber: Data Primer. Gambar 1 Kuadran CIBEST sebelum mendapat bantuan dana zakat produktif dan bimbingan

Berdasarkan kuadran tersebut, ada 14 rumah tangga mustahik yang masuk dalam kategori sejahtera. Sebagaimana kuadran I yang menggambarkan bahwa sebanyak 14 rumah tangga mustahik yang mampu memenuhi kebutuhan materaial dan spiritual. Yaitu terletak pada sumbu positif baik pada garis kemiskinan material dan spiritual walaupun tanpa bantuan dana zakat produktif dari Baznas Kabupaten Cirebon. Meskipun begitu, keluarga sejahtera ini masih mempunyai kekurangan modal untuk usaha. Dan secara fisik juga tempat tinggal mereka mengalami kekurangan.

Untuk kuadran II yaitu menggambarkan rumah tangga mustahik yang masuk dalam kategori miskin material yang terletak pada sumbu negatif pada garis kemiskinan material dan terletak pada sumbu positif pada garis kemiskinan spiritual. Ada 25 rumah tangga mustahik yang mengalami kemiskinan material. Artinya rumah tangga ini belum mampu memnuhi kebutuhan material tetapi mampu memenuhi kbutuhan spiritual walaupun tanpabantuan dana zakat produktif dan bimbingan dari Baznas Kabupaten Cirebon. Dalam skala usaha, Baznas Kabupaten Cirebon mengutamakan pada bagian kuadaran II ini.

Untuk kuadran III, yaitu menggambarkan garis kemiskinan spiritual yang terletak pada sumbu negatif padagaris kemiskinan spiritual dan sumbu positif pada garis kemiskinan material. Dalam kuadran ini terdapat 6 rumah tangga mustahik. Artinya rumah tangga ini mampu memenuhi kebutuhan spiritualnya tetapi masih minim atau masih belum mencukupi kebutuhan spiritualnya.

Terakhir, untnuk kuadran IV yang keduanya terletak pada garis kemiskinan material dan spiritual atau rumah tangga yang mengalami garis kemiskinan absolut. Yaitu kuadran yang menggambarkan rumah tangga mustahik yang tidak mampu mencukupi kebutuhan material dan spiritual. Dalam kuadran ini ada 5 rumah tangga mustahik sebelum adanya bantuan dana zakat produktif dan bimbingan. Setelah mendapatkan bantuan berupa dana zakat produktif untuk progam masyarakat mandiri melalui usaha mikro dan bimbingan rumah mustahik yang bergabung diharapkan mampu berpindah posisi kuadrannya di posisi sumbu positif yang artinya rumah tangga mustahik dapat mencukupi kebutuhan material dan spiritualnya. Di bawah ini kuadran yang sudah penulis gambarkan setelah mendapatkan bantuan dana dan bimbingan dengan Gambar 2 berikut ini:

\begin{tabular}{|l|l|l|}
\multicolumn{1}{|c|}{\begin{tabular}{|l|l|} 
GARIS KEMISKINAN \\
SPIRITUAL
\end{tabular}} & $\begin{array}{l}\text { Miskin material } \\
13 \text { Rumah tangga } \\
\text { (Kuadran II) }\end{array}$ & $\begin{array}{l}\text { Sejahtera 37 Rumah } \\
\text { tangga (Kuadran I) }\end{array}$ \\
\cline { 2 - 3 } & \begin{tabular}{|l|l} 
Miskin Absolut \\
O Rumah Tangga \\
(Kuadran
\end{tabular} & $\begin{array}{l}\text { Miskin Spiritual } \\
\text { 0 Rumah tangga } \\
\text { (Kudran III) }\end{array}$ \\
\hline
\end{tabular}


$(-) \quad \mathrm{Rp}$

$(+)$

GARIS KEMISKINAN MATERIAL

Gambar 2 Kuadran CIBEST sesudah mendapat bantuan dana zakat produktif dan bimbingan. Sumber: Data primer

Posisi kuadran I terdapat 37 rumahtangga mustahik. Artinya rumah tangga ini sudah mampu mencukupi kebutuhan material dan spiritual setelah adanya bantuan dana Zakat dan bimbingan. Posisi kuadran II terdapat rumah tangga mustahik. Yang artinya ada 13 rumah tanngga yang mengalami kemiskinan material tetapi mampu mencukupi kebutuhan spiritual. Sedangkan untuk posisi kuadran III dan IV sebanyak 0 rumah tangga setelah adanya bantuan dana zakat produktif dan bimbingan. Untuk lebih jelasnya, penulis merangkum berdasarkan analisis kuadran CIBEST dengan tabel 2 sebagai berikut:

\begin{tabular}{|l|c|c|}
\hline \multicolumn{1}{|c|}{ Kuadran } & $\begin{array}{c}\text { Sebelum adanya bantuan dana } \\
\text { Zakat produktif dan bimbingan }\end{array}$ & $\begin{array}{c}\text { Setelah adanya bantuan dana } \\
\text { Zakat produktif dan bimbingan }\end{array}$ \\
\hline Kuadran I (Sejahtera) & 14 & 37 \\
\hline Kuadran II (Miskin Material) & 25 & 13 \\
\hline Kuadran III (Miskin Spiritual) & 6 & 0 \\
\hline Kuadran IV (Miskin Absolut) & 5 & 0 \\
\hline Total & 50 & 50 \\
\hline
\end{tabular}

Tabel.2 Rumah tangga Mustahik berdasarkan analisis Kuadran CIBEST (diolah)

Dari tabel di atas, dapat dilihat perbandingan perubahan antara sebelum dan setelah mendapat dana zakat produktif dan bimbingan. Untuk kuadran I jumlah rumah tangga mustahik bertambah menjadi 37 dari 14 begitu juga untuk kondisi kuadran II ada perubahan mustahik menjadi tercukupi setelah adanya bantuan dana dan bimbingan menjadi 13 selanjutnya kuadran III dari 6 rumah tangga mustahik menjadi 0 dan terakhir kondisi miskin absolut sudah mulai berkurang setelah ada bantuan dan bimbingan. Dari analisis ini dapat dijelaskan bahwa dengan adanya bantuan dana zakat produktif dan bimbingan, mampu meningkatkan jumlah rumah tangga mustahik yang sejahtera dan dapat menurunkan jumlah rumah tangga mustahik yang mengalami kondisi . Dengan demikian benar bahwa dana zakat produktif dan bimbingan mampu berpengaruh dan memberikan dampak terhadap kondisi kemiskinan rumah tangga mustahik.

Untuk Analisis Indeks kemiskinan Islami Rumah tangga Mustahik dalam model CIBEST terdiri atas indeks kesejahteraan, indeks kemiskinan material, indeks kemiskinan spiritual, dan indeks kemiskinan absolut. Berdasarkan hasil analisis kuadran CIBEST, telah diketahui jumlah rumah tangga yang masuk dalam masing-masing kategori. Melalui hasil dari kuadran CIBEST tersebut maka akan didapatkan hasil dari perhitungan indeks kemiskinan Islami. Berikut adalah hasil perhitungan indeks kemiskinan Islami yang dapat dilihat di tabel 3 Indeks CIBEST berikut:

\begin{tabular}{|l|c|c|c|}
\hline \multicolumn{1}{|c|}{ Indeks CIBEST } & Tanpa Zakat & Dengan Zakat & Perubahan (\%) \\
\hline Sejahtera & 0,28 & 0,74 & 0,46 \\
\hline
\end{tabular}




\begin{tabular}{|l|c|c|c|}
\hline Miskin Material & 0,5 & 0,26 & 0,26 \\
\hline Miskin Spiritual & 0,12 & 0 & 0,1 \\
\hline Miskin Absolut & 0,1 & 0 & 0 \\
\hline Skor rata-rata & 4,26 & 4,56 & 0,3 \\
\hline
\end{tabular}

Indeks kesejahteraan menggambarkan jumlah rumah tangga mustahik yang masuk dalam kategori rumah tangga sejahtera. Untuk mengetahui dampak dari pendistribusian dana zakat terhadap kesejahteraan rumah tangga mustahik maka penelitian dilakukan tanpa dengan adanya bantuan dana zakat. Berdasarkan tabel diatas jumlah rumah tangga mustahik yang berada pada posisi rumah tangga sejahtera mengalami peningkatan dari 0,28 atau 28 persen menjadi 0,74 atau 74 persen. Artinya, terjadi peningkatan indeks kesejahteraan rumah tangga sebesar 46 persen.

Indeks kemiskinan material yaitu menggambarkan jumlah rumah tangga mustahik yang masuk dalam ketegori miskin secara materialnya namun kaya secara spiritual. Analisis indeks kemiskinan material terhadap rumah tangga mustahik dilakukan tanpa dan dengan adanya bantuan dna zakat yang diberikan oleh BAZNAS Kabupaten Cirebon berdasarkan penelitian yang sudah dilakukan dan memperoleh hasil bahwa tanpa dan dengan bantuan zakat mengalami penurunan sebesar 0,24 atau 24 persen. Hasil tersebut menunjukkan bahwa dengan adanya bantuan zakat dapat menurunkan indeks kemiskinan material rumah tangga mustahik. Hal tersebut dipengaruhi oleh pendistribusian dana zakat produktif yang baik dan bimbingan dari Baznas Kabupaten Cirebon. Hasil survei dan wawancara terhadap rumah tangga mustahik mengatakan terbantu dengan adanya dana zakat produktif yang diberikan untuk mengembangkan dan memulai usaha setelah adanya bantuan dana zakat produktif dan bimbingan-bimbingan terkait manajemen keuangan dan spiritualnya.

Menurunnya indeks kemiskinan material ini juga dipengaruhi oleh pendistribusian zakat produktif dan bimbingan dari Baznas Kabupaten Cirebon. Persepsi sebagian rumah tangga mustahik mengakui bahwa mereka sangat merasa terbantu untuk mengembangkan atau melakukan usaha setelah adanya bantuan dana zakat produktif dan bimbingan-bimbingan mengenai usaha yang diberikan oleh pembimbing dari Baznas Kapubaten Cirebon. Karena fokus zakat ini diberikan kepada rumah tangga mustahik yang belum punya usaha mikro kecil atau sudah mempunyai usaha tetapi mempunyai penghasilan yang relatif kecil di bawah garis kemiskinan. Penurunan indeks kemiskinan material ini juga sama pada penelitian-penelitian sebelumnya ayng meneliti zakat dan dampaknya terhadap kemiskinan atau kesejahteraan mustahik dari sisi material.

Indeks kemiskinan spiritual rumah tangga rumah tangga mustahik, artinya rumah tangga ini termasuk kategori mampu secara materi diukur dengan menggunakan skala likert yang dibuat oleh Beik dan Arsyanti tahun 2004. Mustahik mendapatkan bimbingan dari Baznas kabupaten Cirebon yang diwakilkan oleh BMT Tuan jaler berupa manajemen usaha dan spiritualnya. Indeks kemiskinan spiritual menggambarkan kondisi spiritual yang dialami oleh rumah tangga mustahik. Berdasarkan hasil wawancara dengan mustahik didapatkan nilai 
indeks kemiskinan spiritual sebelum adanya dana zakat dan bimbingan senilai 0,12 atau 12 persen rumah tangga mustahik masuk ke dalam kategori miskin spiritual. Selanjutnya, setelah adanya bantuan dana zakat serta bimbingan nilai indeks ini menurun sebesar 0 persen rumah tangga mustahik yang masuk dalam kategori miskin spiritual. Artinya ada pengurangan sebesar 12 persen atau hilang sama sekali. Menurunnya indeks kemiskinan spiritual disebabkan oleh kesadaran dan lingkungan keluarga mustahik dan bimbingan-bimbingan. Bimbingan yang dilakukan setiap bulan baik yang dijadwalkan atau tidak. Sehingga dampaknya ada pengurangan sebesar 12 persen. hal ini menandakan bahwa rata-rata rumah tangga mustahik semakin meningkat dalam urusan spiritualnya. Peningakatan spiritual para rumah tangga mustahik ditandai dengan menurunnya indeks kemiskinan rumah tangga mustahik.

Analisis variabel kemiskinan spiritual mustahik yang berhak mendapatkan bantuan dana zakat produktif harus mengikuti pembinaan dan pendampingan terlebih dahulu atau secara berkala dari Baznas kabupaten Cirebon. Rumah tangga mustahik ini diberikan bimbingan berupa bagiamana berwirausaha, manajemen keuangan dan juga spiritual. Bimbingan ini berupa kewajiban sebagai muslim, usaha yang baik dan halal, bagiamana mengelola keuangan dengan tepat dan lain-lain. Selain itu rumah tangga mustahik diberikan softkill untuk meningkatkan sisi spiritualnya misalnya keutamaan solat dhuha, tahajud, puasa sunah dan sebagainya.

Indeks kemiskinan absolut menggambarkan kondisi rumah tangga mustahik yang belum mampu memenuhi kebutuhan material dan kebutuhan sipiritualnya. Berdasarkan hasil penelitian, nilai indeks kemiskinan absolut sebelum adanya zakat dan bimbingan dari Baznas kabupaten Cirebon sebesar 0,1 artinya 1 persen rumah tangga mustahik sebelum adanya bantuan dana zakat produktif berada pada kemiskinan absolut. Selanjutnya, setelah adanya bantuan dana zakat dan bimbingan, indeks kemiskinan rumah tangga absolut rumah tangga mustahik mengalami penurunan sehingga nilai indeks setelah zakat sebesar 0 persen rumah tangga mustahik. Pengurangan yang terjadi pada indeks ini tidak terlepas dari bimbingan bimbingan dari Bazanas Kabupaten Cirebon dan di dukung oleh pemerintah serta lingkungan rumah tangga mustahik tinggal. Di lihat dari pengurangan angka indeks ini bantuan dana zakat produktif dan bimbingan mampu memberikan efek positif dalam mengatasi kemiskinan absolut.

Dalam penelitian ini terlihat bahwa rumah tangga mustahik yang awalnya masih dalam kategori dalam kemiskinan absolut, dan setelah adanya bantuan dana zakat produktif dan bimbingan maka setidaknya terdapat 5 rumah tangga mustahik yang mampu memenuhi kebutuhan material tetapi belum mampu memenuhi kebutuhan spiritual sehingga rumah tangga tersebut masuk dalam kategori miskin spiritual dan keluar dari posisi miskin absolut. Tetapi ada pula rumah tangga mustahik yang awalnya masuk dalam kategori miskin absolut, dan setelah adanya bantuan dana zakat produktif dan bimbingan terdapat rumah tangga yang 
mampu memenuhi kebutuhan material dan spitual secara bersamaan dan masuk ke dalam kategori sejahtera.

Hasil keseluruhan dalam penelitian ini ada 23 rumah tangga mustahik yang berasal dari kategori miskin material dan spiritual setelah adanya bantuan zakat produktif dan bimbingan berhsil lepas dan masuk ke dalam posisi rumah tangga sejahtera. Sehingga bantuan bantuan dana zakat produktif dan bimbingan spirittual yang diberikan oleh Baznas kabupaten Cirebon memberikan dampak yang sngat positif untuk mengatasi atau mengurangi kemiskianan dan meningkatkan kesejahteraan rumah tangga mustahik.

Dan hasil analisis indeks kemiskinan islami terhadap rumah tangga mustahik ini menunjukkan bahwa dengan adanya bantuan zakat akan meningkatkan kesejahteraan mustahik dan menurunkan indeks kemiskinan material mustahik

\section{KESIMPULAN}

Zakat Produktif Bagi Pengembangan UMKM berdampak pada berkurangnya pengangguran. Hal ini dikarenakan UMKM dapat menyerap tenaga kerja yang berpendidikan rendah dan hidup dalam kegiatan usaha kecil baik tradisional maupun modern dan kemampuan menyesuaikan diri terhadap kondisi pasar yang berubah dengan cepat dibandingkan dengan perusahaan skala besar yang pada umumnya birokratis selain itu terdapatnya dinamisme manajerial dan peranan kewirausahaan. Dana zakat yang disalurkan ke arah produktif melalui program bergulir bagi para pengusaha mikro yang tergolong mustahik dengan tujuan agar usaha yang dibangun dapat berkembang sampai merubah perekonomian mustahik. Yakni perubahan status dari mustahik menjadi muzaki.

Dengan menggunakan uji t stastistik berpasangan maka hipotesanya menolak Ho. Yaitu, pendapatan rumah tangga mustahik masyarakat mandiri Baznas Kabupaten Cirebon setelah mendapatkan bantuan dana zakat produktif berbeda nyata pada taraf $\alpha=5$ persen terhadap pendapatan rumah tangga mustahik sebelum mendapatkan bantuan dana zakat produktif. Uji $t$ ini menggambarkan rata-rata pendapatan sebelum dan sesudah mendapatkan bantuan dana zakat produktif. Rata- rata pendapatan rumah tangga ini sebelum mendapatkan dana zakat produktif pada kisaran Rp 1.450 .000 di mana rata-rata ini menunjukkan di atas garis kemiskinan material akan tetapi setelah mendapatkan bantuan zakat produktif rata-rata pendapatan mustahik berada pada Rp 1.894 .000 dia mana rata-rata ini meningkat masih di atas garis kemiskinan material. Sehingga peneliti dapat menyimpulkan bahwa adanya bantuan zakat produktif memberikan pengaruh yang sangat signifikan pada perubahan pendapatan mustahik.

Dengan model CIBEST, berdasarkan kuadran CIBEST setelah adanya bantuan dana zakat produktif dan bimbingan ada perubahan yang meningkat menjadi 37 rumah tangga mustahik yang masuk ke dalam kuadran I ( sejahtera) dari 14 rumah tangga mustahik, Kuadran II (miskin material) ada 13 dari 25 rumah tangga mustahik, Kuadran III (miskin spiritual) berjumlah 0 dari 6 rumah tangga mustahik, Kuadran IV (miskin absolut) berjumlah 0 dari 5 
rumah tangga mustahik. Indeks kemiskinan material sebelum adanya bantuan zakat dan bimbingan berjumlah 0,5 atau 50 persen menjadi 0,26 atau 26 persen. Itu artinya kemiskinan material menurun sejumlah 0,24 atau 24 persen keluar dari kondisi miskin material setelah adanya bantuan zakat produktif dan bimbingan. Untuk indeks miskin spiritual dari 0,12 atau 12 persen turun menjadi 0 persen setelah adanya bantuan dana zakat produktif dan bimbingan. Begitu juga miskin absolut dari 0,1 atau 1 persen menjadi 0 persen rumah tangga mustahik keluar dari kondisi miskin absolut. Dan indeks kesejahteraan awalnya 0,28 atau 28 persen, kemudian setelah adanya bantuan zakat produktif dan bimbingan meningkat menjadi 0,74 atau 74 persen. Artinya ada kenaikan sejumlah 46 persen zakat setelah adanya bantuan zakat dan bimbingan dan berhasil masuk ke dalam kategori sejahtera.

\section{DAFTAR PUSTAKA}

Agama, Departemen. Manajemen Pengelolaan Zakat, Direktorat Pengembangan Zakatdan Wakaf. Jakarta, 2005.

Beik, I. S., \&Irawan, T. "Zakat TerhadapKemiskinan Dan Kesejahteraan Mustahik (Kasus: BAZNAS Provinsi Jawa Tengah). AL-MUZARA'AH," 5(1) (2018): 37-50.

Beik, Irfan Syauqi, and Laily Dwi Arsyianti. "Construction of CIBEST Model as Measurement of Poverty and Welfare Indicesfrom Islamic Perspective.Al-lqtishad." Al-lqtishad: Journal of Islamic Economics VII (2015). https://doi.org/10.15408/ijies.v7i1.1361.

Edi Suharto. Membangun Memberdayakan Rakyat, Kajian Strategi Pembangunan Kesejahteraan Sosial \& Pekerjaan Sosial. Bandung: PT Refika Aditama, 2005.

Fitriani, I.R. “Pola Distribusi Zakat Dalam Upaya Meningkatkan Kesejahteraan Jama'ahMajelis Taklim Al-Hidayah Rejosari Gunungpati (Studi Kasus Baznas Provinsi Jawa Tengah)." UIN Walisongo, 2015.

Https.//jabar.bps.go.id. “Garis Kemiskinan Cirebon,” 2016.

Juanda, B. NMetodologi Penelitian Ekonomi Dan Bisniso Title. Bogor, 2009.

Mannan, M.A. MaShort Introduction in Islamic Philosophy, Theology and Mysticism.

England,Oxford,: Oneworld Publications, 1970.

Mubarokah, Isro, Irfan Syauqi Beik, and Tony Irawan. "Impact of Zakat on Proverty and Welfare of Mustahik (Case: BAZNAS Central Java Province)." Jurnal Al-Muzara'ah 5, no. 1 (2017): 3750.

Mursyid. Mekanisme Pengumpuan Zakat, Infak Dan Shadaqaha (Menurut Hukum Syara' Dan UU). Yogyakarta: Magistra Insania Press, 2006.

Nasional, Badan Amil Zakat. Memori Pelaksanaan Tugas Badan Amil Zakat Nasional Kabupaten Cirebon Periode 2011-2016. Kabupaten Cirebon, 2016.

Pratama, Caesar. "Pendayagunaan Zakat Produktif Dalam Mengurangi Kemiskinan Berdasarkan CIBEST Model (Studi Kasus: PT Masyarakat Mandiri Dompet Dhuafa)," 2015.

putra zairisnaldi. "Pemberdayaan UMKM Menurut UU No 28 Tahun 2008 Tentang UMKM." https://www.academia.edu.15010904, 2019.

Statistik, Badan Pusat. "Satistik Kependudukan Cirebon," 2016.

- - - "Satistik Kependudukan Jakarta," 2018. https://www.bps.go.id.

Triwibowo, Darwan. Meretas Arah Kebijakan Sosial Baru Di Indonesia, Jakarta:Pustaka LP3ES. Jakarta: Pustaka LP3ES, 2005. 
Wulansari, Sintha Dewi. "ANALISIS PERANAN DANA ZAKAT PRODUKTIF TERHADAP

PERKEMBANGAN USAHA MIKRO MUSTAHIK (PENERIMA ZAKAT) (Studi Kasus Rumah Zakat Kota Semarang)E," 2013.

www.depok.pos. "Peran Zakat Terhadap Perkembangan UMKM Di Indonesia," 2018. 